\title{
MULTIPERSPEKTIF DALAM MATAPELAJARAN SEJARAH: LANGKAH NYATA MENGHARGAI KEBHINEKAAN DI RUANG KELAS
}

\author{
Susanto Yunus Alfian \\ SMA Negeri 1 Sumberpucung, Kab. Malang
}

\begin{abstract}
Abstrak: Multiperspektif sangat cocok dipakai untuk mengajarkan pemikiran historis. Kita bisa melihat masa lampau dari beragam perspektif. Keragaman perspektif tidak bisa dihindari. Dalam sejarah beragam sumber sejarah harus dimanfaatkan dalam kegiatan pembelajaran di kelas. Siswa harus disadarkan bahwa interpretasi merupakan aspek penting dalam belajar sejarah. Siswa harus diajarkan bahwa dalam sejarah ada beragam interpretasi. Guru perlu mengajarkan multiperspektif dan multi interpretasi kepada siswa. Dengan harapan agar siswa bisa berpikir seperti sejarawan. Untuk mengajarkan multiprespektif kepada siswa, pedagogi kritis sebaiknya digunakan oleh guru sejarah..
\end{abstract}

Kata Kunci: perspektif, multiperspektif, pedagogi kritis, pemikiran historis.

\begin{abstract}
Multiperspective is suitable to teach historical thinking. We could see the past from various perspectives. The diversity of perspectives can't be vaoided. Different sources must be used in the history learning in the class. Students should understand that interpretation is an important aspect on history learning. They should be taught that there are multiple interpretation in history. It is hoped that students could think like a historian. Therefore, teacher should uses critical pedagogy to teach multiperspective ti students.
\end{abstract}

Keywords: perspective, multiperspective, critical pedagogy, historical thinking.

Lembaga-lembaga dunia seperti Dewan Eropa, UNESCO dan Uni Eropa mengakui pentingnya peran pendidikan sejarah (Stradling, 2003). Sejarah sangat penting dalam memupuk sifat saling memahami dan membangun kerukunan. Mereka menganggap bahwa multikulturalisme dan multiperspektifitas perlu ditekankan.

Buku-buku sejarah perlu meningkatkan isi ceritanya yang tidak hanya sekedar mengutamakan ekslusifitas kelompok tertentu. Minoritas juga perlu menjadi bagian dari cerita yang dimasukkan dalam buku sejarah. Pandangan-pandangan yang beragam tentang suatu peristiwa tidak mendapat tempat dalam buku sejarah di sekolah. Padahal pandangan yang beragam tersebut ada di tengah masyarakat dan siswa juga ada di tengah masyarakat juga. Jika itu menjadi sesuatu yang given, maka guru sejarah harus mencari cara lain untuk mengatasinya.

\section{Pendekatan-pendekatan}

multiperspektifitas, multikulturalisme dan pluralis merupakan tantangan pengajaran sejarah yang harus segera diselesaikan. Pendekatanpendekatan terrsebut adalah sangat penting. Pendekatan seperti itu harus dimasukkan dalam kurikulum sejarah.

\section{PERSPEKTIF, MULTIPERSPEKTIF DAN PENGERTIANNYA}

Perspektif adalah suatu pandangan atau suatu cara pandang terhadap situasi atau topik (Kapavik, 2006). Ketika para pakar menyampaikan informasi yang dituangkan dalam bentuk buku, artikel atau bentuk lainnya, ada perspektif-perspektif yang berbeda diantara mereka. Perspektif-perspektif itu tentu akan tergambar dalam pelajaran sejarah yang diterima dan dipelajari oleh siswa.

Perspektif sejarah juga dikenal dengan nama empati sejarah (Ogawa, 2000). Sejarawan di Inggris lebih senang menggunakan istilah empati sejarah, sementara itu sejarawan di Amerika cenderung menggunakan istilah 
perspective taking. Baik istilah empati sejarah atau istilah perspective taking dianggap masih kurang mengena. Oleh karena itu orang cenderung menggunakan perspektif sejarah.

Sejarah dibuat oleh manusia. Sejarah diceritakan oleh manusia. Mengkaji sejarah berarti sama dengan mengkaji perspektif manusia (yaitu perspektif yang didasarkan pada fakta). Tapi kita harus menyadari bahwa pada kenyataannya semua manusia memiliki bias. Hal itu berarti bahwa tidak semua yang ada itu dapat diterima dan disetujui oleh setiap orang. Sejarawan menemukan informasi, merekamnya, menafsirkannya dan hasilnya berupa cerita masa lalu. Hasil penelitian sejarawan tersebut akan disajikan oleh guru kepada siswanya. Akan tetapi guru sejarah harus menyadari bahwa cerita-cerita sejarah bisa miliki beragam perspektif. Berbagai perspektif itu masing-masing berpengaruh dalam pembentukan cerita sejarah. Kemudian cerita tersebut datang atau hadir di kelas, di siswa kita.

Multiperspektif didasarkan pada multi sumber untuk menyajikan sejarah yang lebih utuh, multiperspektif diperlukan.. Beragam sumber tersebut bisa saling melengkapi atau bahkan bisa juga saling bertentangan. Beragam sudut pandang bisa menjadikan sejarah lebih lengkap, tetapi bisa juga menjadikan mereka itu saling berlawanan. Sejarawan cenderung menggunakan beragam sumber dan berkaitan dengan beragam perspektif.

Bila siswa diajak untuk melakukan kegiatan multiperspektifitas, siswa akan mendapatkan pengalaman seperti yang dilakukan para sejarawan. Sejarawan mendapatkan beragam gagasan, beragam cerita, beragam pandangan dalam rangka menggambarkan apa yang terjadi pada masa lampau. Warga negara yang baik harus bisa memahami beragam pandangan, termasuk pandangan yang saling bertentangan. Guru harus mengajarkan siswa untuk menjelaskan sudut pandangnya dan mengekspresikannya dengan cara yang tepat. Begitu juga, guru harus mengajarkan agar mereka mau mendengarkan pandangan yang berbeda dari orang lain. Bahkan juga, guru harus mengajarkan kepada siswa bahwa bukti-bukti untuk mendukung pandangannya itu adalah penting. Guru juga harus mengajarkan kepada siswa tentang bagaimana berargumen dan menalar dengan tepat.

\section{MULTIPERSPEKTIF, GURU DAN SISWA}

Kita harus melihat masa lampau dari beragam perspektif. Kita melihatnya dari sudut pandang pembuat informasi. Sejarah bisa dilihat dari perspektif orang-orang yang terlibat dalam suatu peristiwa. Sejarah juga bisa dilihat dari perspektif orang sejaman yang memberi penafsiran terhadap peristiwa itu. Begitu juga sejarah bisa dilihat dari perspektif orang-orang yang menulis informasi mereka sesudahnya.

Keragaman perspektif tidak bisa dihindari dan memang terjadi. Keragaman perspektif itu meliputi perspektif politik, ekonomi, religi, budaya dan etnik. Guru memerlukan beragam sumber sejarah dan perlu memanfaatkannya dalam kegiatan pembelajaran agar siswa dapat menggunakan beragam informasi dalam mempelajari sejarah. Melalui proses ini siswa diharapkan dapat mengambil intisari dari informasi tersebut dan membuat kesimpulan, atau dengan kata lain membuat deduksi. Siswa bisa juga membandingkan antar sumber. Kemudian mencari perbedaan dari sumber-sumber itu. Dari kegiatan tersebut siswa bisa melihat apakah suatu sumber itu bisa dipercaya atau bermanfaat dalam penelitian sejarah. Selain itu, siswa bisa juga melihat perspektif penulisnya. Jadi mereka bisa mendapatkan gambaran suatu peristiwa masa lalu dari perspektif siapa saja.

Siswa harus disadarkan bahwa interpretasi merupakan aspek penting dalam belajar sejarah. Menggunakan beragam sumber sejarah sangat diperlukan dalam pembelajaran sejarah di kelas. Masa lalu bisa diinterpretasikan oleh siapapun dari sudut pandang apapun. Jadi suatu peristiwa cenderung memiliki beragam interpretasi atau beragam perspektif. Cerita yang ada di buku, cerita yang ada di film, cerita yang dituangkan di karya tulis merupakan interpretasi terhadap masa lalu. Interpretasi itu didasarkan pada bukti. Hasil interpretasi itu bisa bersifat akademik yang hasilnya berupa buku dan jurnal dari para pakar sejarah. Hasil interpretasi itu juga bisa bersifat 
pendidikan seperti pada buku teks, museum dan dokumen sejarah. Hasil interpretasi juga bisa bersifat fiksional seperti novel, film feature, drama. Hasil interpretasi juga bisa bersifat popular seprti sejarah lokal. Dan hasil interpretasi juga bisa bersifat personal, seperti: sejarah lisan. Siswa harus diajak untuk menganalisis interpretasi.

\section{MULTIPERSPEKTIF DAN PEMBELAJARANNYA}

Dengan pembelajaran perspektif sejarah, siswa diajak untuk bisa memahami the inside events atau apa yang ada di dalam suatu peristiwa (Lemisko, 20010). Siswa diajak untuk memahami dan merekonstruksi pikiran-pikiran, emosi-emosi dan motivasi-motivasi orang atau pelaku sejarah atau orang yang berpartisipasi dalam peristiwa sejarah. Ketika siswa diajak untuk melakukan interpretasi sejarah dari suatu sudut pandang tertentu, itu berarti bahwa siswa memandang suatu peristiwa sejarah bukan dari perspektif dirinya sendiri. Ketika kita mengajak siswa untuk mendalami perspektif dari suatu peristiwa, kita telah membantu mereka dalam memahami konteks sosial, politik, budaya dan intelektual masyarakat pada saat peristiwa itu terjadi.

Guru perlu mengajarkan multiperspektif dan multi interpretasi kepada siswa. Dengan harapan agar siswa bisa berpikir seperti sejarawan. Agar siswa menyadari bahwa peristiwa masa lalu bisa dikonstruksi tidak hanya dalam satu cerita. Artinya bahwa satu peristiwa masa lalu bisa tersaji dalam beragam cerita. Setiap peristiwa bisa ditanggapi dalam bentuk beragam interpretasi. Setiap peristiwa bisa mempunyai beragam cerita. Agar siswa juga bisa melakukan pemikiran kritis dalam mempelajari sejarah. Masing-masing sejarawan bisa membuat cerita berbeda-beda untuk satu peristiwa yang sama. Masing-masing sejarawan juga mempunyai penafsiran yang berbeda-beda untuk peristiwa yang sama. Tidak ada satu cerita yang abadi. Cerita sejarah untuk satu peristiwa akan bisa berubah sesuai perubahan waktu. Sejarah selalu ambigu. Dan itu tidak bisa dihindari. Karena adanya ambigu itulah, akhirnya pencarian pengetahuan sejarah akan terus terjadi.

Tentang topik, guru sejarah sebaiknya tidak enggan untuk menggunakan topik-topik yang kontroversial. Topik kontroversial biasanya memiliki multiperspektif yang didalamnya terdiri dari perspektif yang berbeda tajam. Berkenaan dengan topik kontroversial, ada empat macam perspektif yang disampaikan oleh guru yaitu exclusive neutrality, exclusive partiality, neutral impartiality, dan committed impartiality. Guru yang memilih exclusive neutrality menganggap bahwa topik kontroversial sebaiknya tidak diajarkan ke siswa. Sementara itu guru yang memilih exclusive neutrality lebih menginginkan ada satu sisi dari topik itu yang harus diterima dan diberikan ke siswa sebagai sisi yang benar dan yang lain adalah salah. Guru yang berprinsip neutral impartiality memberi kebebasan adanya beragam sudut pandang, dan tidak memegang satu sudut pandang tertentu. Dan guru yang berpegang pada committed impartiality memiliki pandangannya sendiri terhadap topik kontroversial tersebut, dan juga memberikan beragam pandangan yang saling bertentangan.

Sebaiknya guru sejarah tidak hanya menggunakan buku teks saja atau hanya bertumpu pada buku paket saja. Buku teks menjadi bahan yang seharusnya tidak terlalu mendominasi dalam pelajaran sejarah. Siswa jarang sekali mempertanyakan tentang keterpercayaan buku teks. Bagi mereka kredibilitas buku tidak begitu penting. Mereka juga jarang sekali mempertanyakan maksud pengarang dan bias yang ada. Ketika membaca buku teks, siswa menjadi acquiescent assimilators (menerima informasi apa adanya dari buku teks itu). Siswa juga jarang bisa menemukan dengan tepat tentang fakta dan eksplanasi. Dalam pembelajaran yang sangat bertumpu pada buku teks, kemampuan berpikir siswa kurang bisa diasah. Oleh karena itu, guru berkewajiban untuk mengajarkan pemikiran kritis kepada siswanya. Dan guru tidak hanya bertumpu pada buku teks sejarah semata.

Mengajarkan multiperspektif juga perlu dilakukan dengan cermat. Mengajarkan 
multiperspektif dan multi cerita untuk satu peristiwa bisa membuat siswa terbebani dan bisa frustasi. Frustasi bisa terjadi, ketika siswa mencari yang benar namun tidak bisa menemukannya. Disamping itu, siswa umumnya selalu diajari adanya satu jawaban benar dan mengeluarkan jawaban itu lagi di test. Dan mereka sudah terbiasa diberi seperti itu. Jadi kebiasaan diberi jawaban tunggal itu berbeda dengan pengajaran multiperspektif.

Dalam pembelajaran multiperspektif ini, tugas guru memang sungguh berat. Dia harus menyiapkan informasi-informasi yang beragam dan berbeda-beda. Dia tidak hanya menggunakan buku resmi dari pemerintah saja. Dia harus menggunakan beragam sumber sejarah. Sedangkan mencari sumber sejarah merupakan pekerjaan yang tidak gampang.

Buku sejarah dan sumber sejarah bisa dipakai di dalam kelas. Siswa bisa diajak untuk mengenal pandangan atau ideologi penulisnya. Mereka bisa diajak untuk mengenal pandangan yang saling bertentangan dari para penulis buku atau sumber tersebut. Kemudian mereka diajak untuk melakukan koroborasi dari sumber-sumber itu. Artinya sumber-sumber itu bisa saling dipertentangkan dan saling dibandingkan atau saling digunakan untuk melengkapi. Sumbersumber sejarah tersebut bisa berupa: kartun politik, lukisan, editorial surat kabar, buku harian dan surat masa lalu. Sumber tersebut bisa digunakan untuk membantu siswa dalam memahami perspektif, pikiran, dan pengalaman dari pelaku-pelaku sejarah.

Namun demikian buku teks sejarah tidaklah sesempurna yang kita harapkan. Buku teks sejarah tidak dilengkapi dengan sumbersumber primer dan tidak juga melengkapi dengan penyajian multiperspektif. Artinya buku teks tidak menyediakan perangkat yang bisa digunakan untuk terjadinya pemikiran historis. Agar siswa bisa melakukan pemikiran historis, maka perlu menggunakan strategi pengajaran yang melibatkan sumber primer dan multiperspektif.

Maka selanjutnya adalah bahwa guru perlu menggunakan bahan selain dari buku. Sumber primer dan multiprespektif sangat dipentingkan dalam pengajaran sejarah. Siswa harus diberi multiperspektif dan sumber primer. Artinya setiap peristiwa, setiap tokoh, atau teori sejarah harus dilengkapi multiperspektif dan sumber primer (informasi dari pelaku dan saksi peristiwa). Buku teks tidak berisi multiperspektif dan sumber primer. Buku teks jarang sekali dilengkapi dengan kutipan dari dokumennya atau dari sumber primer.

Untuk mengajarkan multiprespektif kepada siswa, pedagogi kritis sebaiknya digunakan oleh guru sejarah. Dengan mendalami sumber primer, siswa bisa terdorong untuk melakukan pemikiran kritis. Dengan demikian, mereka juga melakukan pemikiran historis dan multiperspektif bisa terjadi. Mendalami sumber sejarah primer merupakan kegiatan inkuiri sejarah yang nyata.

Siswa perlu diajari untuk melakukan kegiatan seperti yang dilakukan oleh sejarawan. Sejarawan selalu mengkrtitisi sumber sejarah. Dengan begitu, sejarawan bisa melakukan interpretasi terhadap sumber sejarah. Kemudian dia menceritakan kembali apa yang terjadi pada masa lalu. Cerita yang dihasilkan itu bisa beragam. Antara sejarawan satu dengan sejarawan lainnya bisa berbeda ceritanya untuk menggambarkan suatu peristiwa masa lalu.

Menurut Levstik (1997), ketika guru melakukan pembelajaran multiperspektif pada matapelajaran sejarah, pada dasarnya dia telah menjadikan siswa menjadi warga negara aktif. Warga negara aktif merupakan warga negara yang mampu bergulat dengan dunia yang makin bebas dan makin kompleks dalam kehidupan sehari-hari. Dalam pembelajaran sejarah kita tidak bisa menampikkan atau mengabaikan dampak dari keberagaman ras, etnik, gender, dan afiliasi politik dari masing-masing warga negara. Dan keragaman itu semua bisa berakibat pada beragamnya perspektif dimana siswa menjadi warga negara yang aktif dalam proses berkembangnya bangsa.

\section{IMPLEMENTASI DI KELAS}

Dalam mengajarkan multiperspektif di kelas, beberapa contoh berikut bisa diterapkan.. 
Tentunya masih banyak contoh lain yang luput dari perhatian penulis.

\section{Contoh Pertama}

Untuk mengembangkan multiperspektif, siswa bisa diajak untuk membahas Doktrin Truman tentang penjatuhan Bom Atom pada Perang Dunia II. Siswa membaca berbagai sumber sejarah baik sumber primer ataupun sumber sekunder. Sumber-sumber tersebut bisa berupa: buku harian dari seorang ahli fisika Jepang, memoar Harry S. Truman, keterangan dari tawanan perang, dan beberapa cuplikan dari buku. Pengajarannya merupakan pengajaran pemikiran historis yang menekankan pada multiperspektif dalam sejarah atau juga bisa disebut empati sejarah. Disini siswa diminta untuk menggunakan dokumen.

Untuk mengembangkan multiperspektif, siswa diajak untuk menganalisis sumber-sumber sejarah yang berkaitan dengan keputusan Presiden Truman untu menjatuhkan bom atom di Hiroshima dan Nagasaki (Ogawa \& Field, 2001). Mereka dibagi kedalam kelompok-kelompok yang masing-masing beranggotakan empat orang. Mereka membaca buku sejarah dan berbagai sumber sejarah baik primer maupun sekunder. Sumber- sumber tersebut berisi berbagai perspektif. Perspektif tersebut berasal dari sejarawan, tokoh politik, dan para korban bom itu. Berikutnya, mereka mendalaminya sumbersumber itu. Masing-masing kelompok membuat presentasi lisan dan membuat display museum berkaitan dengan bom atom tesrsebut. Setelah itu masing-masing siswa diminta menyampaikan perspektifnya masing-masing tentang pengeboman Hiroshima dan Nagasaki. Siswa mendiskusikan perspektif mereka dan mendengarkan perspektif atau interpretasi dari teman-temannya. Dalam esainya, siswa harus mencantumkan referensi dari masing-masing perspektif. Mereka harus mengidentifikasi tiaptiap perspektif atau tiap-tiap interpretasi yang ada tentang pengeboman Hiroshima dan Nagasaki.

\section{Contoh Kedua}

Untuk mengembangkan multiperspektif, siswa bisa diajak untuk membahas tentang pengeboman Hiroshima dan Nagasaki dengan membandingkan perspektif dua pihak yang berbeda. Siswa diberi kesempatan untuk menjelaskan perbedaan dan persamaan yang ada antara orang Amerika dan orang Jepang tentang penjatuhan bom di Hiroshima dan Nagasaki (Ogawa, 2001). Ada empat topik yang dibandingkan, yaitu:

1. Pembuatan Bom Atom: Siapa yang membuat bom itu? Bagaimana Bom itu diuji? Apa motif dan tujuan Amerika untuk menggunakan bom tersebut?

2. Peran Rusia. Apa peran Rusia dalam pengeboman itu?

3. Penjatuhan Bom Atom di Hiroshima dan Nagasaki. Bagaimana buku-buku teks di negara-negara yang berkaitan dengan Bom Atom itu?

4. Akibat Pengeboman. Bagaimana kondisi orang-orang yang mati dari jatuhnya Bom tersebut? Atau bagaimana kondisi orang-orang yang luka akibat jatuhnya Bom Atom tersebut?

\section{Contoh Ketiga}

Untuk mengajarkan multiperspektif di kelas, guru bisa juga menggunakan foto-foto masa lalu. Siswa dikenalkan dengan sumber primer seperti foto, peta, surat atau sumber tertulis lainnya. Mintalah siswa untuk mengamati fotofoto itu dalam rangka mendapatkan tanda-tanda atau petunjuk dengan melihat latarbelakang, pakaian, gedung-gedung. Kegiatannya berupa langkah-langkah berikut:

1. Investigasi: "siswa diminta untu mengamati dengan seksama, dan membuat catatan rinci yang menjadi petunjuk dalam memahami orang atau tempat dalam foto tersebut."

2. Guru memberi waktu cukup agar siswa bisa mengamati bersama kelompoknya.

3. Pertanyaan: "siswa diminta untuk menggunakan petunjuk-petunjuk di foto tersebut untuk menceritakan tentang orang di foto tersebut, menjelaskan petunjuk-petunjuk 
tersebut, petunjuk-petunjuk itu diberi makna.

4. Beri kesempatan siswa untuk mendiskusikan di kelas. Siswa diminta untuk menemukan petunjuk-petunjuk yang bisa menjelaskan tentang budaya dari orang yang ada di foto. Siswa menjelaskan alasan mengapa petunjuk tersebut bisa membantu dalam menjelaskan orang di foto tersebut. Siswa menjelaskan peran pakaian dan latar belakang dalam menjelaskan suatu negara atau suatu kota.

\section{KESIMPULAN}

Dengan pembelajaran perspektif sejarah, siswa diajak untuk bisa memahami the inside events atau apa yang ada di dalam suatu peristiwa. Guru perlu mengajarkan multiperspektif dan multi interpretasi kepada siswa. Tentang topik, guru sejarah sebaiknya tidak enggan untuk menggunakan topik-topik yang kontroversial. Topik kontroversial biasanya memiliki multiperspektif yang didalamnya terdiri dari perspektif yang berbeda tajam. Sebaiknya guru sejarah tidak hanya menggunakan buku teks saja atau hanya bertumpu pada buku paket saja. Buku teks sejarah tidak dilengkapi dengan sumber-sumber primer dan tidak juga melengkapi dengan penyajian multiperspektif. Maka selanjutnya adalah bahwa guru perlu menggunakan bahan selain dari buku. Sumber primer dan multiprespektif sangat dipentingkan dalam pengajaran sejarah.

Untuk mengajarkan multiprespektif kepada siswa, pedagogi kritis sebaiknya digunakan oleh guru sejarah. Siswa perlu diajari untuk melakukan kegiatan seperti yang dilakukan oleh sejarawan. Sejarawan selalu mengkrtitisi sumber sejarah. Dengan begitu, sejarawan bisa melakukan interpretasi terhadap sumber sejarah. Ketika guru melakukan pembelajaran multiperspektif pada matapelajaran sejarah, pada dasarnya dia telah menjadikan siswa menjadi warga negara aktif. Warga negara aktif merupakan warga negara yang mampu bergulat dengan dunia yang makin bebas dan makin kompleks dalam kehidupan sehari-hari.

Untuk mengembangkan multiperspektif, tentu ada banyak cara. Tetapi dalam tulisan ini penulis hanya mampu memberi tiga contoh saja. Pertama, siswa diajak untuk membahas Doktrin Truman tentang penjatuhan Bom Atom pada Perang Dunia II. Siswa membaca berbagai sumber sejarah baik sumber primer ataupun sumber sekunder. Kedua, siswa membandingkan perspektif antara orang Amerika dan orang Jepang. Ketiga, guru menggunakan foto-foto masa lalu.

\section{DAFTAR RUJUKAN}

Anderson, L. W., Krathwohl, D. R., Airasian, P. W., Cruikshank, K. A., Mayer, R. E., \& Pintrich, P. R. (2001). A Taxonomy for Learning, Teaching, and Assessing: A Revision of Bloom's Taxonomy of Educational Objectives (Completed edison). New York: Longman.

Bennett, S. 2004. The use of Multiperspectivity when Teaching History in Secondary and Upper Secondary Schools: an example of the United Kingdom. Disajikan dalam Seminar "Multiperspectivity In Teaching and Learning History" dilaksanakan di Nicosia, Cyprus, 24 - 27 November 2004

Britt, M. A., \& Aglinskas, C. (2002). Improving students' ability to identify and use source information. Cognition and Instruction, 20 (4), 485-522.

Clarke, L. W. \& Whitney, E. 2009. Walking in Their Shoes: Using MultiplePerspectives Texts as a Bridge to Critical Literacy. The Reading Teacher, 62 (6), 534-530.

Kapavik, R. D. (2006). Interrupting traditional Social Studies classroom: perspectives of US history teachers. 
Disertasi. The University of Texas at Austin.

Lemisko, L. (2010). The inside out: diaries as entry points to historical perspective taking. Canadian Social Studies, 44 (1), 38-54.

Mayer, R. E. (2002). Rote versus meaningful learning. Theory Into Practice, 41 (4), 226-232.

Metzger, M. J., \& Flanagin, A. J. (2013). Credibility and trust of information in online environments: the use of cognitive heuristics. Journal of Pragmatics, 59, 210-220.

Ogawa, M. (2001, April 10-14). Building multiple historical perspectives: an investigation of how middle school students are influenced by different perspectives. The Annual meeting of the American Educational Research Association. Seatle, WA.

Ogawa, M. (2000, November 16-19). Sixth grade students' development of historical perspective: world war II and the atomic bombong of Hiroshima and Nagasaki. Annual Meeting of the National Council fro the Social Studies. San Antonio, TX.

Ogawa, M., \& Field, S. L. (2001). Realities of the introduction of multiple historical perspectives during a middle school study on WW II. The Annual Meeting of the College and university faculty assembly of the National Councilfor the Social Studies. Washington, DC.

Schmitter, E. 2013. Native American History and Perspectives in United States History Textbooks. Tesis. Ohio University.

Stobaugh, S. (2013). How to teach students to evaluate information: a key common core skill. Larchmont, NY: Eye On Education.

Stradling, R. 2003. Multiperspectivity in history teaching: a guide for teachers. Council of Europe. 